\title{
Deporting the American Dream: Immigration Enforcement and Latino Foreclosures
}

\author{
Jacob S. Rugh, ${ }^{a}$ Matthew Hall ${ }^{b}$
}

a) Brigham Young University; b) Cornell University

Abstract: Over the past decade, Latinos have been buffeted by two major forces: a record number of immigrant deportations and the housing foreclosure crisis. Yet, prior work has not assessed the link between the two. We hypothesize that deportations exacerbate rates of foreclosure among Latinos by removing income earners from owner-occupied households. We employ a quasi-experimental approach that leverages variation in county applications for $287(\mathrm{~g})$ immigration enforcement agreements with Immigration and Customs Enforcement and data on foreclosure filings from 2005-2012. These models uncover a substantial association of enforcement with Hispanic foreclosure rates. The association is stronger in counties with more immigrant detentions and a larger share of undocumented persons in owner-occupied homes. The results imply that local immigration enforcement plays an important role in understanding why Latinos experienced foreclosures most often. The reduced home ownership and wealth that result illustrate how legal status and deportation perpetuate the racial stratification of Latinos.

Keywords: immigration; Latinos; mixed-status households; foreclosures; stratification

Citation: Rugh, Jacob S., and Matthew Hall. 2016. "Deporting the American Dream: Immigration Enforcement and Latino Foreclosures." Sociological Science 3: 1053-1076.

Received: September 26, 2016 Accepted: November 2, 2016

Published: December 8, 2016

Editor(s): Jesper Sørensen, Stephen Morgan

DOI: $10.15195 / \mathrm{v} 3 . a 46$

Copyright: (C) 2016 The Author(s). This open-access article has been published under a Creative Commons Attribution License, which allows unrestricted use, distribution and reproduction, in any form, as long as the original author and source have been credited. (C) (i)
VER the past decade, Latinos in the United States have been affected by two major crises, neither of which has fully ended. First, immigrant deportations reached record levels-rising from 165,168 in 2002 to 319,382 in 2007 and 438,421 by 2013, or 3.6 million deportations in total (Gonzalez-Barrera and Krogstad 2014; U.S. Department of Homeland Security 2014). Deported immigrants have been almost exclusively Latino: 94 percent of those deported since 2005 have been Mexican or Central American despite their two-thirds share of all unauthorized persons (Passel and Cohn 2014; U.S. Department of Homeland Security 2014). The impacts of deportations are not limited solely to the unauthorized because millions live in "mixed status" households along with documented persons (Taylor et al. 2011). In the second crisis, Latino households lost their homes to foreclosure more often than any other ethno-racial group in the recent housing crash (Bocian et al. 2011; Hall, Crowder, and Spring 2015b; Rugh 2015a). Yet, while millions of Latino households were devastated by the crises of record deportations and foreclosures, we are unaware of prior work that connects the two.

In this article, we aim to establish an empirical link between Latino deportations and Latino foreclosures. We hypothesize that the surge in Latino deportations in the mid-2000s that preceded the foreclosure crisis exacerbated rates of foreclosure among Latino homeowners. Because Latino immigrants often live in mixed legal status, owner-occupied households, we expect the deportation of a wage-earning adult in the household to raise the risk of home foreclosure. Latino household foreclosure rates should be uniquely affected because 85 percent of deportees are estimated to be male immigrants from Latin America previously in the labor force 
(Golash-Boza and Pierrette Hondagneu-Sotelo 2013; Rosenblum and McCabe 2014; U.S. Department of Homeland Security 2014).

To identify these effects, we leverage geographic and temporal variation in application and approval of local 287(g) immigration enforcement agreements with Immigration and Customs Enforcement (hereafter ICE). We examine how the deportation of Latino immigrants may be causally related to Latino foreclosure rates by taking advantage of variation in the outcomes of 287(g) applications and employing inverse probability of treatment weights to a difference in difference framework (see Kostandini, Mykerezi, and Escalante 2014; Potochnick, Chen, and Perreira 2016).

\section{Background}

In the post-9/11 era, increased immigration enforcement in the U.S. interior has led to a record number of deportations of immigrants already living here (i.e., removals, not returns of recent border crossers). Total interior removals increased steadily from 122,587 in 2002 to 207,776 in 2006, then rose further to 300,135 in 2009 (2.4 times the 2002 total) and remained elevated at 282,156 in 2012 (Immigration and Customs Enforcement 2013). ${ }^{1}$ This intensification of interior enforcement efforts coincided with an unprecedented dispersal of Latino immigrants across the United States. Until 1990, for instance, around nine in 10 recent Mexican immigrants settled in California, Illinois, and Texas, a share that dropped to five in 10 by 2005 (Massey and Capoferro 2008). Ironically, increased United States-Mexico border enforcement in the 1990s has been causally linked to Latino immigrant dispersal, which appears to have partly precipitated the ensuing interior enforcement. (Bohn and Pugatch 2015; Massey, Durand, and Pren 2016).

The surge in immigrant detentions also increased in lockstep with Latino household foreclosure rates, which also rose to record levels (Figure 1). According to 2013 data from the Panel Survey of Income Dynamics, cumulative foreclosure rates since 2001 stood at 19 percent for Latinos, 15 percent for blacks, and 8 percent for whites (Hall et al. 2015b). In the early years of the U.S. housing crash, blacks and Latinos appeared to be equally devastated by foreclosures because of factors such as discriminatory subprime lending (Rugh and Massey 2010).

However, the discrepancy between black and Latino foreclosure rates that emerged and widened over time has spurred inquiry into the role of nativity and legal status in explaining the Latino disadvantage (Allen 2011; Kochhar, GonzalezBarrera, and Dockterman 2009; Pfeiffer et al. 2014; Rugh 2015a; Rugh 2015b; Rugh and Allen 2015). For example, Cuban immigrants (who enjoy immigration protections) and Puerto Ricans (who are U.S. citizens) were not as negatively affected as Mexican Americans by the housing crisis (Cahill and Franklin 2013; Kuebler and Rugh 2013).

\section{Section 287(g) Local Immigration Enforcement}

The spike in interior immigration enforcement has largely been a result of changes in policies dictating the role of local governments in facilitating detention. In 
18.2

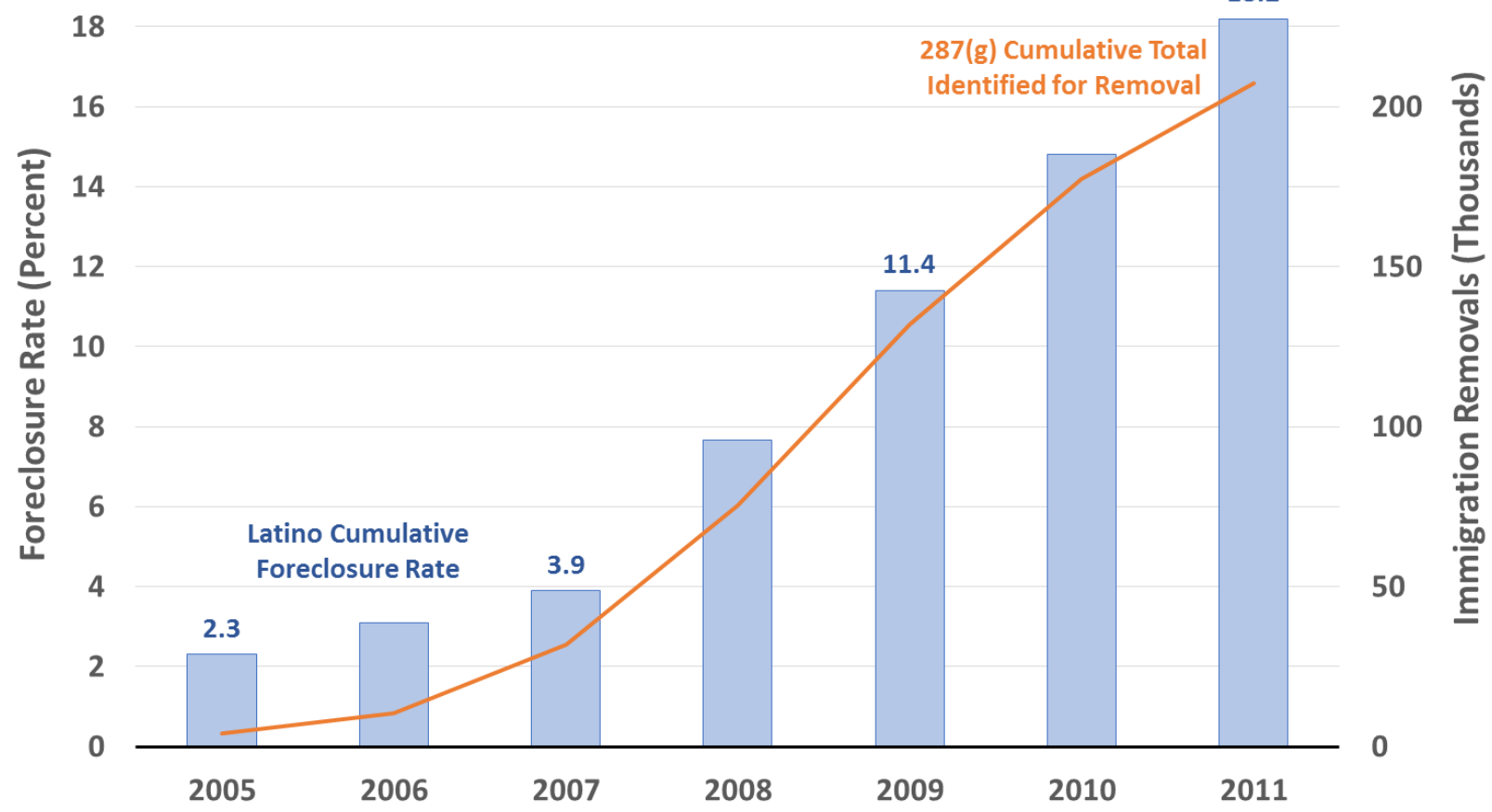

Figure 1: Latino foreclosure rate and local 287(g) immigrant enforcement, 2005-2011. Sources: Hall, Crowder, and Spring (2015b); Immigration and Customs Enforcement (2013).

particular, growth in deportations traces its origins to section 287(g) of the 1996 Illegal Immigration Reform and Immigrant Responsibility Act, which effectively deputized local police officers as immigration agents and gave local police agencies considerable power in apprehending and detaining anyone suspected of being in violation of federal immigration law (U.S. Government Accountability Office 2009).

The $287(\mathrm{~g})$ immigration enforcement agreements provided local officials unprecedented latitude to pursue, detain, and deport immigrants already living in the United States. In the late 1990s and early 2000s, section 287(g) was adopted as a very focused program on criminal removals, but with the rapid growth of Latinos in new destinations (particularly in the southeast), 287(g) became viewed as an effective local tool to remove all unauthorized persons (see Capps et al. 2011). Consequently, the proliferation of the agreements happened in mid-2000s and the counties that signed agreements during this time were home to more than 5 million Central Americans and Mexicans and an estimated 3 million undocumented immigrants, or one-quarter of the total in the United States at the time (authors' calculations).

Compared to the more widely studied Secure Communities initiative (e.g., Miles and Cox 2014; Watson 2013), the 287(g) program data better suit our purposes for three reasons. First, although Secure Communities was first piloted in late 2008 in a handful of counties, it was mainly implemented from 2010 to 2013, too late to cause foreclosures in 2006 to 2010. Secure Communities was more focused on criminal removals because it followed 287(g). Its policies, while still criticized on 
civil rights grounds, were less controversial compared to the allegations of racial profiling against officials carrying out 287(g) enforcement (e.g., Capps et al. 2011; Lacayo 2010). Second, the rollout of 287(g) was uneven across counties in various states without relation to the United States-Mexico border. In the case of Secure Communities, time and distance from the border were correlated: it was rolled out first in border regions and then slowly into the rest of the interior United States (Miles and Cox 2014).

The final reason we select 287(g) local enforcement is that it drove a historic increase in noncriminal deportations (Capps et al. 2011; Watson 2013). In the absence of 287(g) enforcement, many otherwise law-abiding Latino immigrants may not have been deported (Golash-Boza 2015). The noncriminal share of deportations for traffic offenses or no offense ranged tremendously across locations and tended to be highest in counties undergoing rapid Latino population growth (Capps et al. 2011). Thus, $287(\mathrm{~g})$ data provide a better proxy for immigrant detentions that otherwise would not have occurred in the context of the criminal justice system.

To the extent that $287(\mathrm{~g})$ enforcement and related initiatives increasingly removed longtime residents for noncriminal offenses in established undocumented and mixed status families, they would be more likely to be members of homeowner households. In this regard, 287(g) noncriminal removals come closer to identifying the variation in immigration deportations most likely to affect owner-occupied Latino households. Based on the prior literature and the contours of 287(g) agreements, we hypothesize that local $287(\mathrm{~g})$ enforcement will lead to more foreclosures in counties with higher rates of home ownership among households with Latino immigrants (greater exposure to the risk of foreclosure). The next section details the conceptual model for this hypothesis.

\section{Linking Deportation, Home Ownership, and Foreclosure}

Figure 2 presents our conceptual model of pathways from deportation to foreclosure. Latino deportations and Latino out-migration in response to increased local immigration enforcement decrease the number of immigrant adult wage earners in owner-occupied Latino households. Many households pool resources across families and mixed legal statuses to achieve and sustain homeownership (Golash-Boza 2015; Guelespe 2013; Schueths 2015). Some argue that immigrants are drawn to homeownership because of its symbolism in the "American Dream" narrative and are willing to enter homeownership by stretching their earning power (Thomas 2013). ${ }^{2}$

Latino immigrants put down roots in the United States, including household home ownership across mixed legal statuses. Among those deported, the median length of U.S. residence is 14 years (Brabeck and Xu 2010). In studies of mixed legal status couples, home ownership ranged from 40 percent to 50 percent, and the presence of extended family was common (Guelespe 2013; Schueths 2015). Legal permanent residents are more likely to be homeowners than the undocumented and are also deported via local police-based enforcement (Golash-Boza 2015; Hall and Greenman 2013). In the 42 counties with 287(g) agreements analyzed in this article, 72 percent of the 1.2 million households with at least one unauthorized adult 


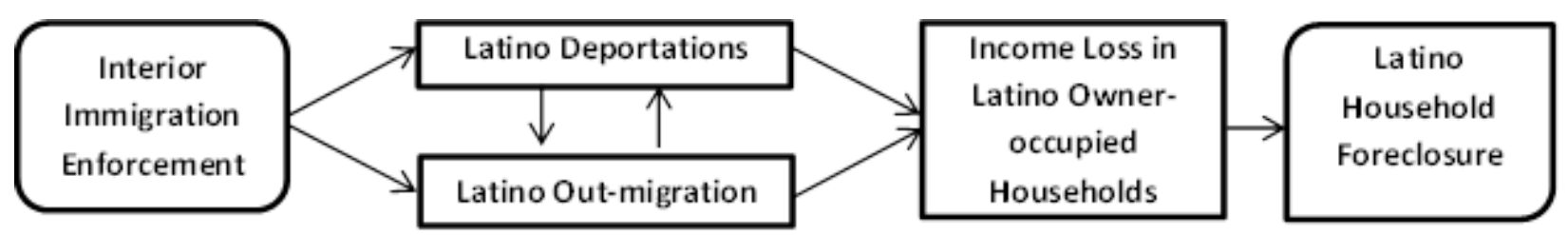

Figure 2: Conceptual model of Latino deportations and Latino household foreclosures.

contained a documented adult household member, and 32 percent of the estimated 3 million undocumented immigrants lived in owner-occupied homes.

Moving across our conceptual model in Figure 2, we hypothesize that the ensuing loss of income formerly devoted to mortgage payments raises the likelihood of household foreclosure. When deportations of Latino immigrants began to accelerate in 2006 to 2008, wage-earning adults were removed from these Latino homeowner households, which subsequently contributed to an elevated rate of foreclosures in 2008 to 2011. Most deported immigrants previously contributed to household mortgage payments, even though they were not likely cosigners on actual home loans (Guelespe 2013; Rugh and Allen 2015; Zayas 2015). ${ }^{3}$ More than 90 percent of those deported wage earners are men; their labor market participation rates and incomes tend to exceed those of the women left behind, who are often primary caretakers of dependent children (Golash-Bozaa and Pierrette Hondagneu-Sotelo 2013; Rosenblum and McCabe 2014).

Prior research strongly suggests that household income loss plays a role in our conceptual chain between immigration enforcement and foreclosure. The consensus of most research estimates postdeportation losses in household income to be around 50 percent (Capps et al. 2015; Chaudry et al. 2010; Koball et al. 2015; Brabeck and $\mathrm{Xu}$ 2010). In addition, expenditures on legal fees and immigration bonds drained the finances of many immigrant families facing deportation, exacerbating income losses (Koball et al. 2015). Evidence of reductions in migrant remittances also suggests that enforcement reduces the incomes of households with deported immigrants. Undocumented Mexican migrants residing in counties that adopted 287(g) agreements reduced their remittances by 35 percent postadoption compared to those in other counties; in contrast, remittances did not decline among documented migrants (Amuedo-Dorantes and Puttitanun 2014).

At the end of the chain of risk factors in Figure 2, home foreclosure is the final consequence. Qualitative and quantitative findings point to reduced home ownership as the ultimate outcome of immigration enforcement and household income loss. ${ }^{4}$ Among a sample of Latino families that owned their homes and experienced an immigration arrest, incomes losses were severe and half of them lost their homes within one year (Chaudry et al. 2010). ${ }^{5}$ Because the time from detention to deportation, mortgage default, and subsequent foreclosure usually spans more than one year, in our model we expect the impact of enforcement to last longer, perhaps several years. In summary, we find evidence for the linkages in our conceptual model in the prior literature on mixed status households and couples, immigrant home ownership, and the effects of detention and deportation on incomes. 


\section{Data and Methods}

To evaluate the impact of deportations on foreclosures, we compile data from a variety of sources to assemble a panel file of relevant county-level information. Our measures of county foreclosures are based on the population of foreclosure filings as collected by RealtyTrac. Specifically, we obtained the complete database of all foreclosure-related documents collected in virtually every county in the country by RealtyTrac between 2005 and 2012. The full database of more than 20 million foreclosure documents was reduced to "first-visible" foreclosures, which refers to the point when a foreclosed residential property is either auctioned or repossessed (see Hall, Crowder, and Spring 2015a for additional information on the algorithms used during this process). In total, this procedure estimates that 9.5 million homes were foreclosed between 2005 and 2012 (see Hall et al. 2015b).

The RealtyTrac foreclosure filings include detailed information on the location and timing of foreclosure but lack information on the ethnoracial identity of homeowners. In order to estimate the number of foreclosures for major racial/ethnic groups, we use Summary File 1 of Census 2000 to assign a probability weight to each foreclosure based on the racial composition of the census block in which the housing unit is located. For example, a foreclosure occurring in a block that was 70 percent white and 30 percent black would be classified as 0.7 white and 0.3 black. ${ }^{6}$ The same procedure is used to delineate the number of housing units occupied by each racial group in every census block in 2000. We use these imputed counts of foreclosures and housing units to calculate race-specific foreclosure rates (foreclosures per 100 housing units) annually for each year from 2005 to 2012. Among the 433 counties that form our main analytic sample, the average annual foreclosure rate is 1.05 percent, with average annual rates for whites ( 0.96 percent) being lower than rates for blacks (1.10 percent) and Hispanics (1.01 percent). ${ }^{7}$ As expected, there is substantial variation over time in these rates. Average annual foreclosure rates for Hispanics, for example, were 0.24 percent in 2005 but 1.62 percent in 2010 . Moreover, variation across counties is considerable: at the peak of the crisis, for instance, Hispanic foreclosure rates were 11.6 percent in Maricopa, Arizona, but 0.02 percent in Wichita, Texas.

The focal independent variable in our analysis is whether a county has implemented a 287(g) agreement with the Department of Homeland Security. The full set of historical and active agreements was released by ICE via the Freedom of Information Act (FOIA) (U.S. Department of Homeland Security 2016) and contains the date of implementation and type of agreement (jail or task force). The majority of these agreements were made by county sheriff's offices, although several were to municipalities within counties, which we apply to the entire county. ${ }^{8}$ We also obtained information through a separate FOIA request on the number of persons identified for removal by ICE as well as those who were detained. In FY 2010, for example, 47,252 individuals were identified for removal and 80.2 percent of these individuals were ultimately detained by ICE. We use these counts to describe the intensity of the impact of enforcement by dividing the sum of removals in each county by the total foreign-born population of the county. This approximation of the share of immigrants detained by 287(g) is highly variable, with Alamance, North 
Carolina, having identified 24 percent of its immigrant population for removal while Fairfield, Connecticut, identified 0 percent. Lastly, we obtained information via the FOIA (U.S. Department of Homeland Security 2015) on the counties (or jurisdictions within counties) that submitted an application to enter into a 287(g) agreement but were rejected by the Department of Homeland Security. Detailed information on the reason for denial were not included in the FOIA response, but media reports and correspondence between agencies indicates that rejections were a result of a county not having the resources to staff immigration-related intakes or having the capacity to hold those identified for removal.

To account for differences across counties in immigration enforcement, we use propensity scores methods (described below) to predict $287(\mathrm{~g})$ participation as a function of a set of covariates expected to be related to local enforcement. To capture demographic variation across counties, we include measures of the percent of the population that is Hispanic, the percent of Hispanics of Caribbean descent, the percent foreign-born, and total population size (logged), all of which are derived from Census 2000. Median household income (from Census 2000) is included to account for economic differences. To capture differences in housing markets and to consider the possibility that immigration enforcement was more intense in markets with rapid housing cost growth, we include measures of the percent of the population that lived in owner-occupied housing, 2000-2005 housing value growth rates from Zillow.com, the percent of home loans underwritten with no documentation, the percent of loans with high-cost rate spreads, and the average backend debt-to-income ratio among borrowers (see Rugh 2015a). Indicators for census region and metropolitan status are also included.

A central variable in the treatment model and in moderation analyses is the number of unauthorized immigrants in a county. To estimate county-level unauthorized populations, we employ the data fusion approach developed in Capps et al. (2013) that applies correlations between legal status and other characteristics observed in the 2001 Survey of Income and Program Participation to public-use microdata samples (PUMS) from Census 2000 using multiple imputation (see Bachmeier, Van Hook, and Bean 2014; Van Hook et al. 2015). This process is used to generate two relevant estimates: the number of unauthorized persons and the percent of unauthorized immigrants living in owner-occupied housing. This reliance on PUMS data to complete this process, combined with the exclusion of three additional counties (Rockingham, New Hampshire, Strafford, New Hampshire, and Douglas, Oregon) with incomplete foreclosure data, restricts our main analytic sample to 433 counties with boundaries that closely follow census PUMAs. ${ }^{9}$

\section{Analytic Approach}

Our analysis leverages variation in the timing and location of 287(g) programs to estimate the impact of immigration enforcement on home foreclosures. In the first stage of our analysis, we determine the propensity score that a county implements a 287(g) program as the conditional probability of assignment to the treatment, given a set of demographic, economic, and housing covariates. The probit is expressed as:

$$
\operatorname{probit}(T=1 \mid X)=\phi\left(\gamma_{0}+\gamma_{1} X+\epsilon\right)
$$


where $T$ is an indicator of whether a county implemented 287(g) and $X$ represents the covariates discussed above, including total and foreign-born populations, unauthorized shares, racial composition, median incomes, ownership rates, risky lending measures, housing price growth, census region, and metropolitan status. We estimate this model separately for the full analytic sample of 433 counties and the smaller quasi-experimental set of counties that applied for 287(g) (including the rejected applicants).

We use the propensity scores from these models to generate weights equal to the inverse of the probability of treatment (IPT):

$$
w_{i}=\frac{T_{i}}{P(T=1 \mid X)}+\frac{1-T_{i}}{1-(P(T=1 \mid X))}
$$

This gives greatest weight to treated $(287[\mathrm{~g}])$ counties with the lowest probability of treatment and untreated counties with highest probability of treatment (see Morgan and Todd 2008). As discussed below, this model is successful in balancing covariates between treated and control groups and more so in the quasi-experimental sample than in the larger set of counties.

The main part of our analysis assesses the impact of immigration enforcement on foreclosures using a doubly-robust difference in difference model with IPT weighting. The basic model is expressed as follows:

$$
\text { foreclosures }_{k c t}=\beta_{0}+\sum_{j=-2}^{3}\left(\tau_{c t}=j\right)+\alpha_{s}+\delta_{t}+\lambda_{s} t+\mathbf{X}_{c} \mathbf{f i}_{1}+\varepsilon_{c t}
$$

where foreclosures $k c t$ is the foreclosure rate for racial/ethnic group $k$ in county $c$ and year $t ; \tau_{c t}$ is a set of event time dummies, defined in two-year intervals such that it includes the two periods (up to four years) before implementation of $287(\mathrm{~g})$, the implementation year, and the three periods (up to six years) following implementation. State fixed effects are represented by $\alpha_{s}, \delta_{t}$ are year effects, and $\lambda_{s} t$ are state-specific linear time trends; $\boldsymbol{X}_{\boldsymbol{c}}$ is the set of covariates in the treatment model. These estimates incorporate the IPT weights described above; robust standard errors are clustered at the county-level. Our main interest lies in the estimates of $\tau_{c t}$, which indicate how foreclosure levels differed between counties with and without 287(g) before and after implementation of the program.

\section{Results}

Participation in the 287(g) program, and immigration enforcement more broadly, is variable across time and space. These two sources of variation are shown in the two panels of Figure 3, which identify the location of all 287(g) participants (panel A) and the timing of their implementation (panel B). More specifically, the map identifies all counties that applied for 287(g) between 2005 and 2012, with green shades identifying counties that were approved for participation and red shades representing counties with applications that were rejected. The map shows considerable variable across the country in $287(\mathrm{~g})$ involvement, but noticeable clusters 


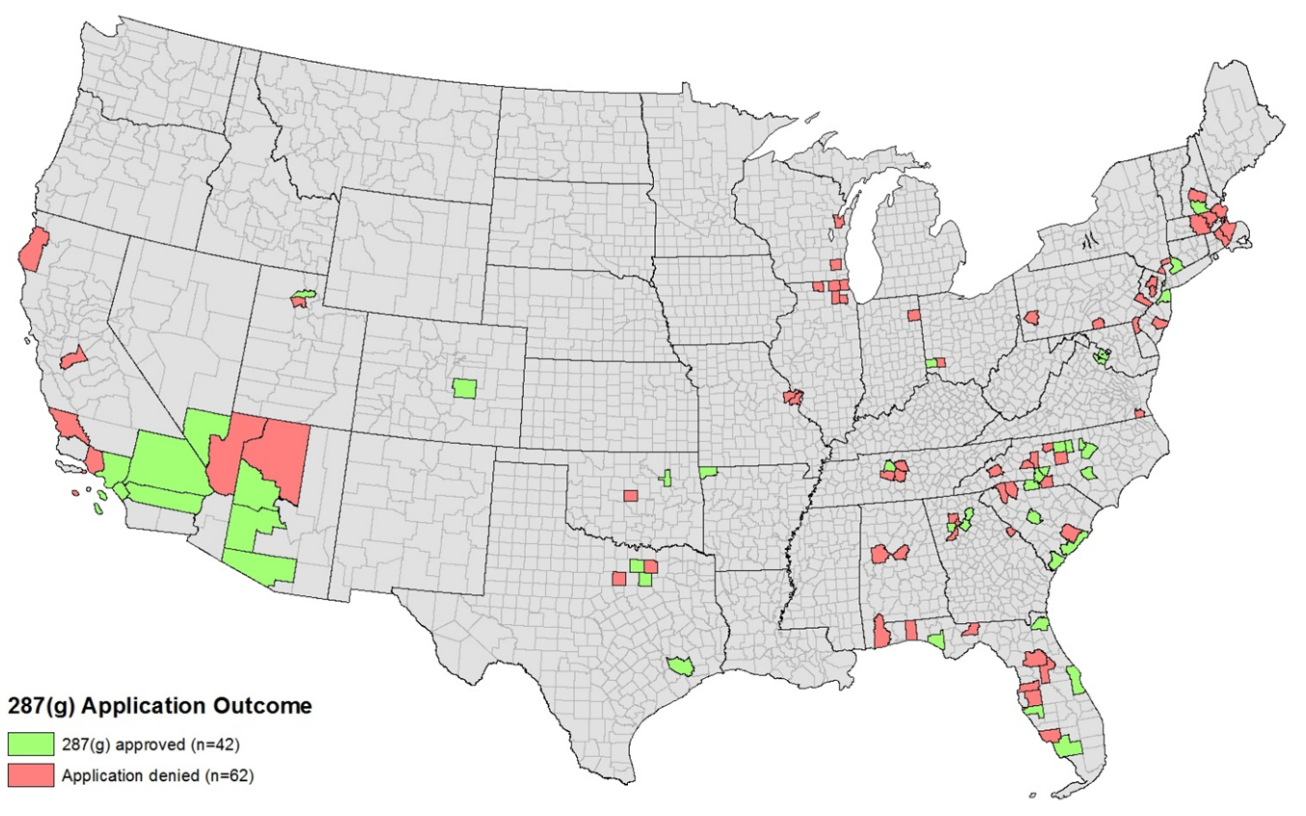

(a)

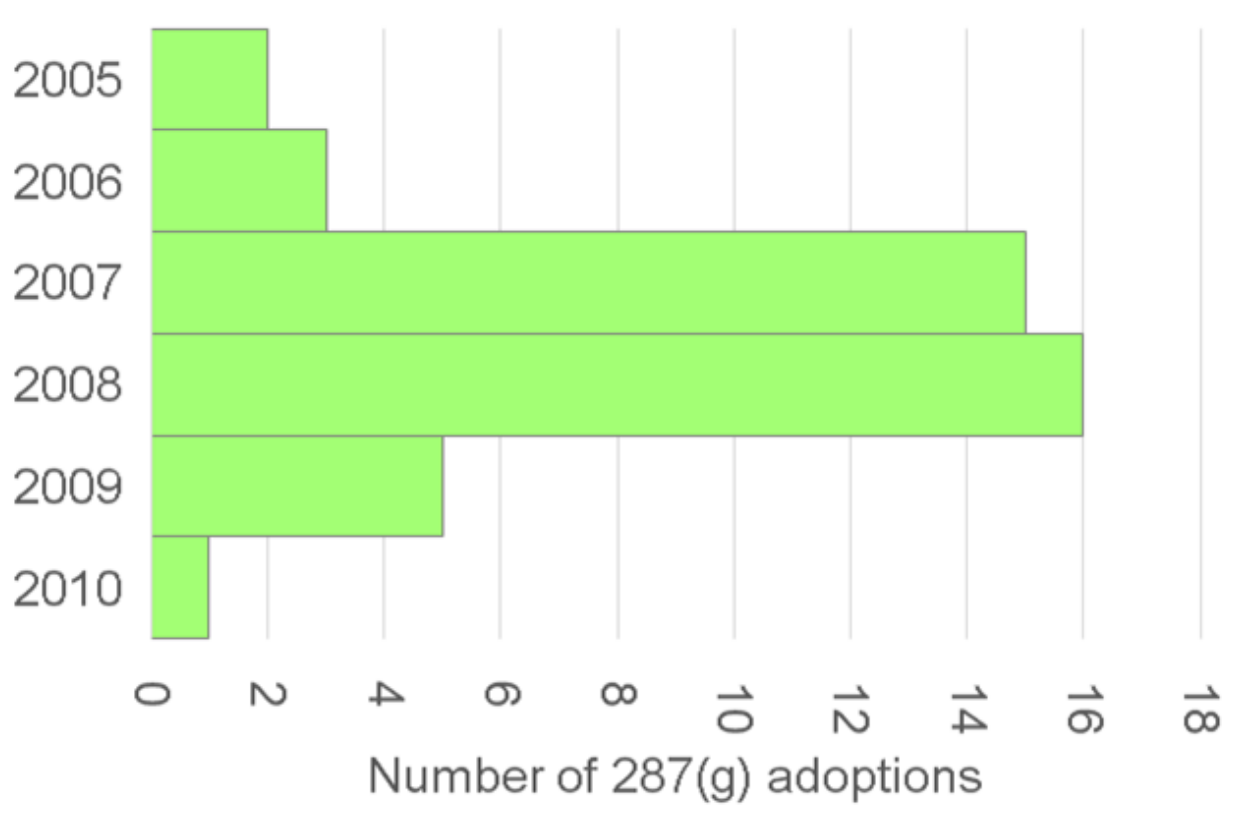

(b)

Figure 3: Spatial and temporal variation in $287(\mathrm{~g})$ county applications. Panel A: Counties that applied for 287(g), by application outcome. Panel B: Year of implementation for approved 287(g) counties. Sources: Immigration and Customs Enforcement (2013); Potochnick, Chen, and Perreira (2016). 
of counties in the southwest (especially around Phoenix and Los Angeles) and the southern Atlantic regions (e.g., in areas near Atlanta, Charlotte, and Raleigh).

Panel B of Figure 3 graphs the timing of 287(g) implementation among counties with accepted applications. About two-thirds of counties initiated their programs in 2007 or 2008, but several-including San Bernardino, California, (2005) and Mecklenburg, North Carolina, (2006)—were early adopters, and others reached agreements later (e.g., Yavapai, Arizona, [2008] and Gwinnett, Georgia, [2009]).

\section{Predicting 287(g) Participation}

The first stage in our analysis predicts the likelihood that a county will implement a 287(g) agreement. The results of this treatment model are summarized in Table 1. Specifically, Table 1 shows average marginal effects from the probit model of 287(g) participation for our two analytic samples of counties: the broad set of counties with valid information on key covariates $(\mathrm{N}=433)$ and the subset of counties that applied for 287(g) ( $\mathrm{N}=104)$.

The model estimates indicate that only three county characteristics are significantly related to $287(\mathrm{~g})$ implementation: region, total population, and the percent of Hispanic immigrants estimated to be unauthorized. The estimates suggest that larger southern counties with high unauthorized shares were most likely to adopt a 287(g) agreement. The estimates for the smaller set of counties that applied for 287(g) are similar in magnitude but are less precise. Specifically, the coefficient estimates on unauthorized shares, total population, and region suggest a tendency for counties with accepted agreements to have larger unauthorized shares and to be located in the southern or western regions, but none of these coefficients are significantly different from zero.

We employ IPT propensity weighting to balance covariates between control and treatment counties. In the larger set of counties, the overidentification test for balancing has a $\chi^{2}=0.94(p<1.00)$; for the set of 287(g) applicant counties $\chi^{2}=4.50(p=0.99)$. Weighted means for individual covariates in the treatment model are shown in Table A1 of the online supplement. As shown there, a significant difference between treated and control counties in unauthorized shares exists even with the IPT weighting. However, in the sample of $287(\mathrm{~g})$ applicant counties, balancing of all individual covariates is achieved.

\section{The Impact of $287(\mathrm{~g})$ on Foreclosures}

Results from models evaluating the impact of 287(g) adoption on county foreclosures are shown in Table 2. The table is organized to show the treatment effects across event time, and models are estimated separately for overall county foreclosure rates and rates for Hispanics. All models incorporate IPT weights and include state and year fixed effects, state-specific trends, and the treatment model controls.

The results in Table 2 show clearly that 287(g) adoption was associated with an increase in county foreclosures. Specifically, the estimates indicate that foreclosure rates in 287(g) counties did not differ from non-287(g) counties in the years preceding implementation of the program-i.e., the coefficients on the pre-287(g) terms are very small and statistically indistinguishable from zero. The coefficients in the 
Table 1: Average marginal effects from probit of 287(g) participation.

\begin{tabular}{|c|c|c|}
\hline & $\begin{array}{c}\text { All counties } \\
(\mathrm{N}=433)\end{array}$ & $\begin{array}{c}287(\mathrm{~g}) \text { applicant } \\
\text { counties }(\mathrm{N}=104)\end{array}$ \\
\hline$\%$ unauthorized of Hispanic immigrants & $\begin{array}{r}0.004^{+} \\
(0.001)\end{array}$ & $\begin{array}{c}0.006 \\
(0.005)\end{array}$ \\
\hline$\%$ Hispanic & $\begin{array}{c}0.002 \\
(0.002)\end{array}$ & $\begin{array}{c}0.003 \\
(0.013)\end{array}$ \\
\hline$\%$ foreign born & $\begin{array}{c}-0.003 \\
(0.004)\end{array}$ & $\begin{array}{c}0.010 \\
(0.021)\end{array}$ \\
\hline$\%$ Caribbean of Hispanics & $\begin{array}{r}0.002 \\
-0.005\end{array}$ & $\begin{array}{l}-0.005 \\
-0.028\end{array}$ \\
\hline Median household income (in $\$ 1,000$ s) & $\begin{array}{c}0.000 \\
(0.002)\end{array}$ & $\begin{array}{c}0.000 \\
(0.008)\end{array}$ \\
\hline Total population (log) & $\begin{array}{c}0.090^{\dagger} \\
(0.021)\end{array}$ & $\begin{array}{c}0.109 \\
(0.083)\end{array}$ \\
\hline$\%$ homeowners & $\begin{array}{c}-0.001 \\
(0.003)\end{array}$ & $\begin{array}{r}-0.010 \\
(0.008)\end{array}$ \\
\hline Housing value growth & $\begin{array}{l}0.000 \\
0.000\end{array}$ & $\begin{array}{c}0.000 \\
(0.002)\end{array}$ \\
\hline$\%$ high cost of home loans & $\begin{array}{r}-0.007^{*} \\
(0.003)\end{array}$ & $\begin{array}{r}-0.005 \\
(0.012)\end{array}$ \\
\hline$\%$ no documentation of home loans & $\begin{array}{r}-0.005 \\
(0.005)\end{array}$ & $\begin{array}{c}0.001 \\
(0.014)\end{array}$ \\
\hline Average debt:income of borrowers & $\begin{array}{c}0.022 \\
(0.017)\end{array}$ & $\begin{array}{r}-0.029 \\
(0.058)\end{array}$ \\
\hline Region $($ Northeast $=$ ref) & & \\
\hline Midwest & $\begin{array}{c}-0.032 \\
(0.030)\end{array}$ & $\begin{array}{c}-0.087 \\
(0.179)\end{array}$ \\
\hline South & $\begin{array}{r}0.133^{+} \\
(0.044)\end{array}$ & $\begin{array}{c}0.187 \\
(0.164)\end{array}$ \\
\hline West & $\begin{array}{c}0.015 \\
(0.038)\end{array}$ & $\begin{array}{c}0.170 \\
(0.264)\end{array}$ \\
\hline Metro county $(=1)$ & $\begin{array}{c}0.051 \\
(0.055)\end{array}$ & $\begin{array}{c}0.176 \\
(0.183)\end{array}$ \\
\hline
\end{tabular}

$+p<0.05 ; * p<0.10$

years following adoption, however, indicate that foreclosure rates are substantially (and significantly) higher in 287(g) counties. The estimate of 0.6356 in the two years after implementation indicates that foreclosure rates in $287(\mathrm{~g})$ counties were about 0.64 percentage points higher than in non-287(g) counties. This effect is equivalent to 0.42 standard deviations from the mean foreclosure rate. There is no strong evidence that the $287(\mathrm{~g})$ effect wanes over the first two postimplementation periods, as the confidence intervals on the post-287(g) coefficients are all overlapping. As expected, the results for Hispanics are stronger, with our models suggesting that 
Table 2: Difference-in-difference estimates of 287(g) participation on county foreclosure rates (2005-2012).

\begin{tabular}{lcc}
\hline & Overall foreclosures & Hispanic foreclosures \\
\hline Event time indicators (vs. non-287g counties) & & -0.048 \\
Pre 287(g), 3-4 years & 0.039 & $(0.087)$ \\
& $(0.134)$ & -0.045 \\
Pre 287(g), 1-2 years & -0.051 & $(0.112)$ \\
& $(0.124)$ & 0.149 \\
287(g) implementation year & 0.014 & $(0.130)$ \\
& $(0.238)$ & $0.740^{\dagger}$ \\
Post 287(g), 1-2 years & $0.636^{\dagger}$ & $(0.255)$ \\
& $(0.290)$ & $0.619^{\dagger}$ \\
Post 287(g), 3-4 years & $0.554^{\dagger}$ & -0.224 \\
& -0.228 & $0.882^{\dagger}$ \\
Post 287(g), 5-6 years & 0.056 & $(0.262)$ \\
& $(0.327)$ & Yes \\
IPTW Weights & Yes & Yes \\
Year fixed effects & Yes & Yes \\
State fixed effects & Yes & Yes \\
State trends & Yes & Yes \\
Treatment covariates & Yes & $3,464(433)$ \\
N of observations (counties) & $3,464(433)$ & \\
\hline
\end{tabular}

$+p<0.05 ; * p<0.10$; standard errors clustered at county level.

287(g) was associated with a sizeable increase in rates of Hispanic foreclosure in all three postimplementation periods.

Table 2 provides evidence that county immigration enforcement augmented local foreclosures. Yet, the estimates from Table 2 are potentially confounded by characteristics of counties that select them into 287(g) participation. While the IPT weights help to adjust for observable differences between $287(\mathrm{~g})$ and other counties, unobservable features of counties are likely to bias our estimates. Moreover, the propensity scores are not completely successful in this full sample to balance on all key characteristics-most importantly, the share of Hispanics who are unauthorized. To partly resolve these issues, our preferred analysis is based on the set of counties that applied for $287(\mathrm{~g})$, including both the rejected and accepted applications.

Results from models for the 104 counties that applied for 287(g) are summarized in Table 3. The estimates in Table 3 provide compelling evidence that 287(g) deepened the housing crisis, with overall foreclosure rates being about 0.4 percentage points (or 0.20 standard deviations) higher in counties that adopted a 287(g) program relative to those that applied but did not adopt the program. The estimates are somewhat imprecise, with only the effect for one to two years following adoption reaching significance at the 10 percent level, but the pattern of difference is strongly consistent with the expectation that $287(\mathrm{~g})$ intensified foreclosure rates.

The second to fourth columns of Table 3 report estimates for each of the major racial/ethnic groups, generally showing,--as expected,-stronger effects on 
Table 3: Difference-in-difference estimates of 287(g) participation on county foreclosure rates (2005-2012) among 287(g) applicant counties.

\begin{tabular}{lcccc}
\hline & $\begin{array}{c}\text { Overall } \\
\text { foreclosures }\end{array}$ & $\begin{array}{c}\text { Hispanic } \\
\text { foreclosures }\end{array}$ & $\begin{array}{c}\text { Black } \\
\text { foreclosures }\end{array}$ & $\begin{array}{c}\text { White } \\
\text { foreclosures }\end{array}$ \\
\hline Event time indicators (vs. non-287g counties) & & & & \\
Pre 287(g), 3-4 years & 0.044 & 0.086 & -0.055 & 0.139 \\
& $(0.175)$ & $(0.160)$ & $(0.220)$ & $(0.173)$ \\
Pre 287(g), 1-2 years & -0.066 & 0.009 & -0.236 & 0.112 \\
& $(0.151)$ & $(0.155)$ & $(0.144)$ & $(0.174)$ \\
287(g) implementation year & -0.020 & -0.053 & -0.339 & 0.231 \\
& $(0.229)$ & $(0.266)$ & $(0.205)$ & $(0.259)$ \\
Post 287(g), 1-2 years & 0.448 & $0.696^{*}$ & 0.176 & $0.632^{\dagger}$ \\
& -0.29 & -0.376 & -0.276 & -0.298 \\
Post 287(g), 3-4 years & 0.352 & $0.725^{*}$ & 0.218 & $0.436^{*}$ \\
& $(0.243)$ & $(0.401)$ & $(0.201)$ & $(0.241)$ \\
Post 287(g), 5-6 years & 0.268 & 0.334 & 0.091 & 0.351 \\
& $(0.410)$ & $(0.497)$ & $(0.382)$ & $(0.390)$ \\
IPTW Weights & Yes & Yes & Yes & Yes \\
Year fixed effects & Yes & Yes & Yes & Yes \\
State fixed effects & Yes & Yes & Yes & Yes \\
State trends & Yes & Yes & Yes & Yes \\
Treatment covariates & Yes & Yes & Yes & Yes \\
N of observations (counties) & $832(104)$ & $832(104)$ & $832(104)$ & $832(104)$ \\
\hline
\end{tabular}

$+p<0.05 ; * p<0.10$; standard errors clustered at county level.

Hispanic foreclosures than other groups. The posttreatment estimates for black foreclosures are all positive but comparatively small and not statistically significant. The estimates for whites, however, indicate that $287(\mathrm{~g})$ may have had broader impacts on foreclosures. As our race-specific foreclosures are constructed by weighting each foreclosure by the racial composition of its census block, we are potentially misclassifying "white" and "Hispanic" foreclosures if Hispanics living in integrated or whiter neighborhoods face high risks of foreclosure. To the extent that this is true, our estimates for Hispanic foreclosures will likely be biased downward and the estimates for white foreclosures pushed upward. To test this possibility, we calculated Hispanic-white segregation for all counties in our analysis and estimated models separately for counties with low Hispanic-white segregation (dissimilarity $<0.6)$ and those with high segregation (dissimilarity $\geq 0.6$ ). ${ }^{10}$ These estimates are shown in Table A2 of the online supplement and demonstrate clearly that the effects of 287(g) on white foreclosures were limited to those areas where whites and Hispanics were more likely to coreside. 
Table 4: Difference-in-difference estimates of 287(g) participation on county Hispanic foreclosure rates (20052012) among 287(g) applicant counties.

\begin{tabular}{lcccc}
\hline & Weak & Strong & Low Undoc & High Undoc \\
Treatment & Treatment & Ownership & Ownership \\
\hline Event time indicators (vs. non-287g counties) & & & & \\
Pre 287(g), 3-4 years & 0.101 & -0.069 & 0.131 & -0.343 \\
& $(0.133)$ & $(0.347)$ & $(0.079)$ & $(0.929)$ \\
Pre 287(g), 1-2 years & 0.075 & -0.047 & 0.002 & -0.257 \\
& $(0.148)$ & $(0.228)$ & $(0.108)$ & $(0.617)$ \\
287(g) implementation year & 0.029 & 0.078 & -0.220 & -0.151 \\
& $(0.342)$ & $(0.235)$ & $(0.190)$ & $(0.558)$ \\
Post 287(g), 1-2 years & 0.622 & $1.230^{*}$ & 0.136 & $1.158^{*}$ \\
& $(0.404)$ & $(0.694)$ & $(0.284)$ & $(0.685)$ \\
Post 287(g), 3-4 years & 0.649 & $1.063^{\dagger}$ & $0.453^{*}$ & $1.348^{*}$ \\
& $(0.493)$ & $(0.424)$ & $(0.238)$ & $(0.730)$ \\
Post 287(g), 5-6 years & -0.272 & $0.890^{*}$ & 0.556 & 0.921 \\
& $(0.645)$ & $(0.488)$ & $(0.372)$ & $(0.742)$ \\
IPTW Weights & Yes & Yes & Yes & Yes \\
Year fixed effects & Yes & Yes & Yes & Yes \\
State fixed effects & Yes & Yes & Yes & Yes \\
State trends & Yes & Yes & Yes & Yes \\
Treatment covariates & Yes & Yes & Yes & Yes \\
N of observations (counties) & $712(89)$ & $616(77)$ & $520(65)$ & $312(39)$ \\
\hline
\end{tabular}

$\mathrm{N}=104$ counties; $\uparrow p<0.05 ; * p<0.10 ;$ standard errors clustered at county level.

\section{Exploring Mechanisms of the Impacts}

This analysis suggests that immigration enforcement increased home foreclosures among Hispanic households. In the final stage of our analysis, we consider the moderating roles of enforcement intensity and the presence of unauthorized persons in owner-occupied housing as a means to explore possible pathways connecting 287(g) to housing foreclosure. Specifically, in the first two columns of Table 4, we stratify our sample of $287(\mathrm{~g})$ counties into those that detained a large share $(>5$ percent) of the local immigrant population and those that detained relatively small shares $(<5$ percent).

The results clearly show that the impact of $287(\mathrm{~g})$ on Hispanic foreclosures was especially strong in counties with high detention rates (with strong treatment intensity) but smaller and statistically insignificant with 287(g) counties with lower detention rates (with weaker intensity). These relationships are shown in graphical form in Figure 4, where the red circles represent point estimates for weakly enforced counties, and the blue Xs represent strongly enforced counties (attached to 90 percent confidence intervals).

Our conceptual model of the link between deportations and foreclosures views the loss of adult wage earners in homes with mortgages as one of the central 
3.0

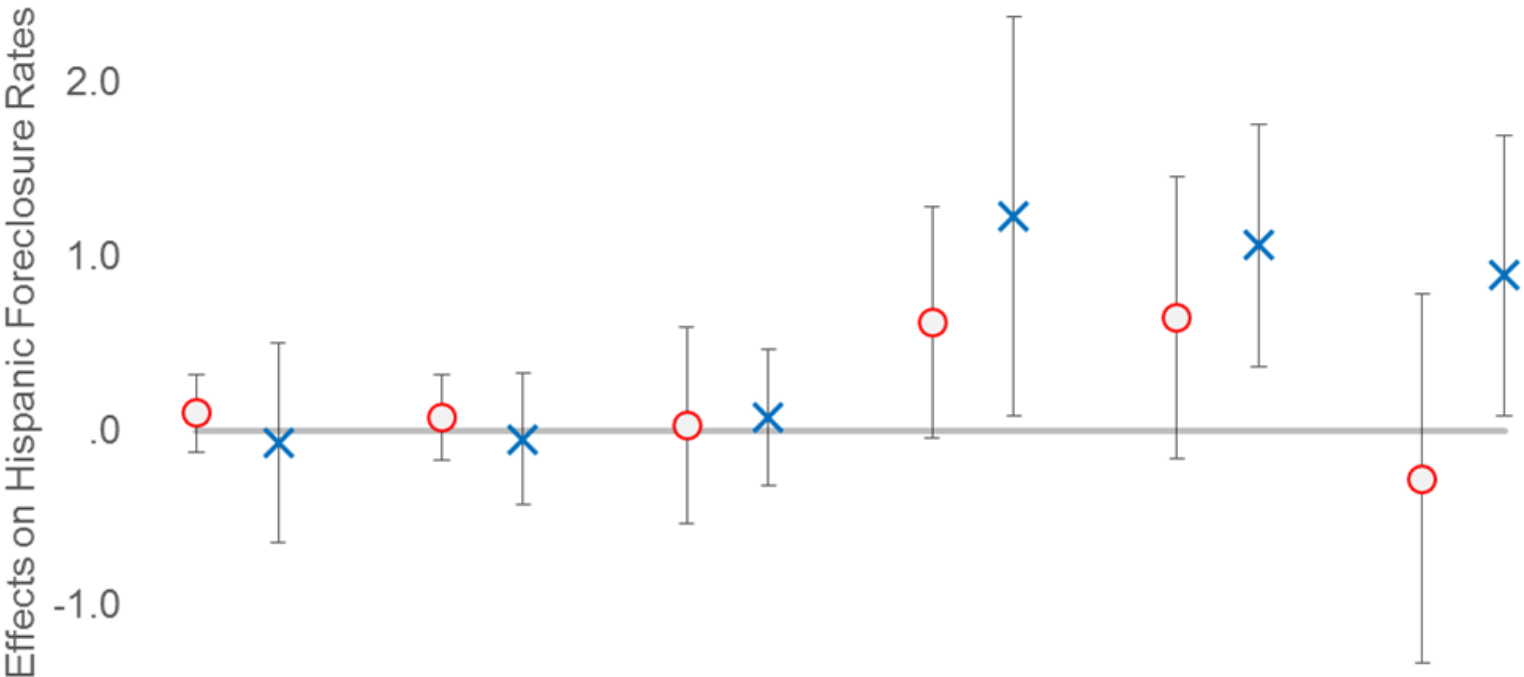

$-2.0$

\section{$-2$ \\ 0 $+2+4$ \\ Years before/after $287(\mathrm{~g})$ implementation}

$+6$

\section{OWeakly enforced $\times$ Strongly enforced}

Figure 4: Effects of 287(g) on Hispanic foreclosure rates, by enforcement intensity.

mechanisms. Following this logic, the impacts of $287(\mathrm{~g})$ on foreclosures should be heightened in counties where a larger portion of the unauthorized live in owneroccupied homes. The third and fourth columns of Table 4 present results that are consistent with this argument. Specifically, the post-287(g) effect estimates are substantially higher in counties where the unauthorized have high ownership occupancy (more than 30 percent reside in owner-occupied housing) than in areas where the unauthorized are less likely to live in owned homes ( $<30$ percent). Again, we illustrate this difference graphically in Figure 5, which clearly shows the large and significant point estimates of $287(\mathrm{~g})$ on foreclosures in the years following adoption for counties where unauthorized persons are more likely to live in owned homes.

\section{Discussion}

In this article, we took advantage of county variation in the timing and geographic location of $287(\mathrm{~g})$ applications to model difference in difference estimates (combined with inverse probability of treatment weights) of the effect of local immigration 
3.0

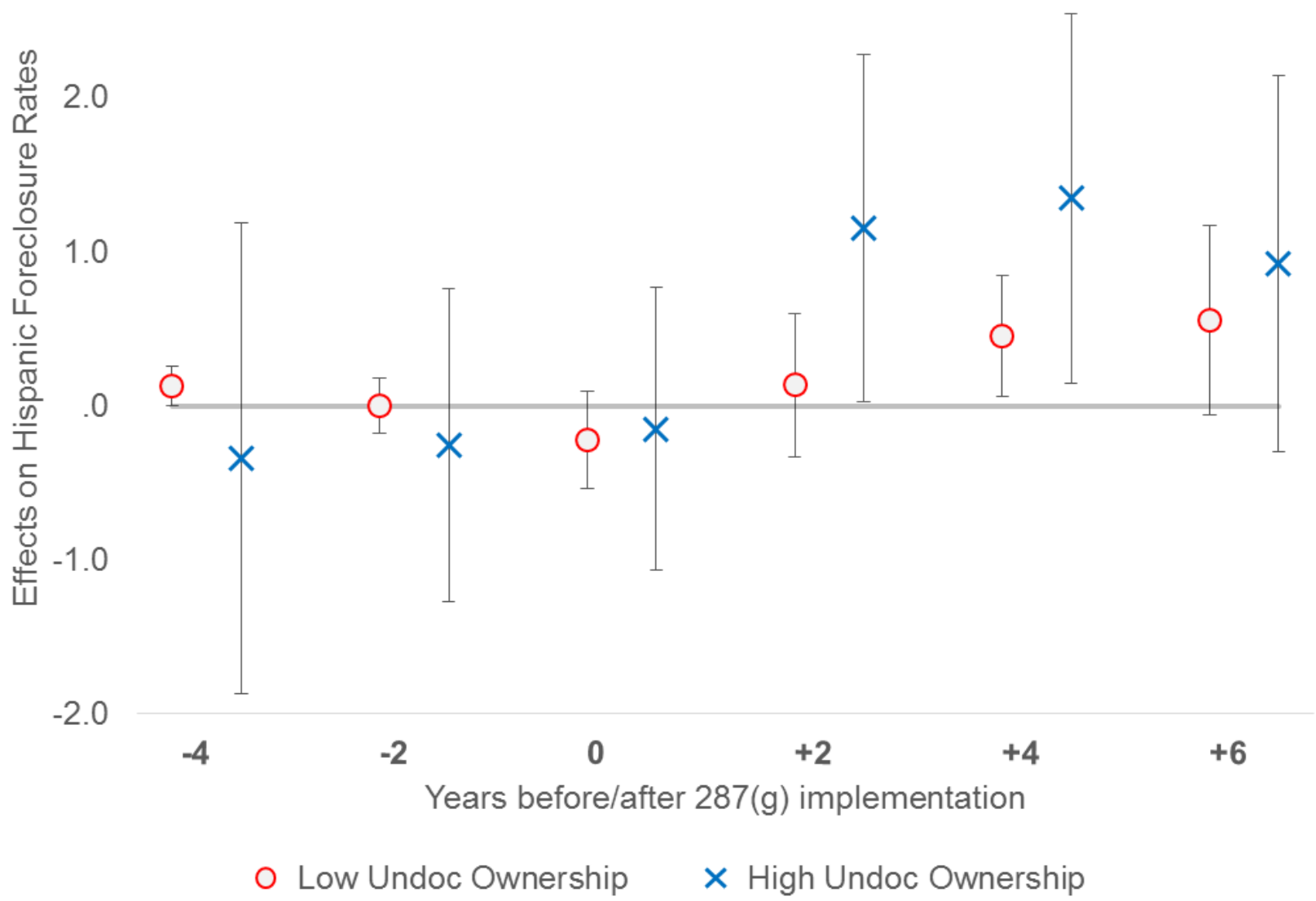

Figure 5: Effects of 287(g) on Hispanic foreclosure rates, by \% of undocumented in owner-occupied housing.

enforcement on rates of Hispanic foreclosure between 2005 and 2012. Our results document a clear pattern in counties that implemented a 287(g) agreement experienced a surge in Latino foreclosures. More specifically, our preferred models estimate that in the two years following adoption, Latino foreclosure rates in 287(g) counties were about 0.68 percentage points higher than in non-287(g) counties (or 0.39 standard deviations larger than the mean). Consistent with our expectations, the magnitude of this association is nearly twice as large in counties where more immigrants are identified for deportation and where a higher share of the undocumented population resides in owner-occupied homes.

While our analysis is the first that we are aware of to propose and detect an effect of immigrant deportations on Latino foreclosures, our analysis does face potential limitations. Our quasi-experimental estimates are not as precise because of the limited statistical power that stems from the sample size. We note that our ecological data using census block racial shares are indirect estimates of foreclosures among Latino households; at the same time, the data represent the most comprehensive database on foreclosures that we are aware of. Future analyses should explore the 
use of individual data nested within local immigration enforcement districts to gain greater leverage on the proposed mechanisms and overcome these power issues. We caution that we cannot interpret our estimates to be strictly causal. However, the results may be interpreted as reasonably close to causal if we assume that counties with accepted and rejected 287(g) applications are similar in terms of unobservable characteristics that predict foreclosure. This assumption seems reasonable in light of previous scholarship that employs similar strategies of statistical inference to infer causality. Finally, we note that our conceptual model is not intended to portray potential effects on non-Latino households, local businesses that cater to Latino immigrants (Hagan, Rodriguez, and Castro 2011), or the ultimate impact on Latino household wealth and opportunity (Keister, Vallejo, and Borelli 2015). We view this latter limitation, however, as a favorable invitation for further research on the compounding effects of these processes.

Our analysis has important implications for housing and immigration policy as well as theoretical and empirical work on immigrant incorporation and Latino residential stratification. During the housing crash and ensuing Great Recession, increased local immigration enforcement that removed Latino immigrants from homeowner households worked at cross-purposes with federal initiatives to help troubled homeowners stay in their homes (see Immergluck 2015). As Menjívar (2014) recently concluded, interior immigration enforcement has "far-reaching and unintended consequences" (p. 357). By lowering incomes, home ownership, and immigrant demand for housing in owner and rental markets, deportations may partly explain the relatively prolonged slump in housing markets in metropolitan regions with high levels of enforcement like Phoenix and Atlanta. Future work should investigate the possible impact of immigration enforcement on housing policies and outcomes that affect the broader population.

By joining the research on immigration enforcement and home ownership, our analysis also contributes to the theoretical and empirical scholarship of immigrant incorporation (Alba and Nee 2005; Bean, Brown, and Bachmeier 2015; Myers 2007; Park and Myers 2010; Telles and Ortiz 2008; Vallejo 2012), illegality (Chávez 2008; De Genova 2002; Dreby 2015; Massey, Durand, and Pren 2014; Menjívar 2006), mixed status households (Capps and Fortuny 2006; Capps et al. 2015; Cardoso et al. 2014; Dreby 2012), and the residential stratification of Latinos (Fischer and Tienda 2006; Hall 2013; Hall and Stringfield 2014; Rugh 2015a). Our conceptual model and analysis results strongly suggest that unauthorized status leads to a chain of events from deportation, lost household income, foreclosure, and, ultimately, lost wealth. The results thus lend support to the delayed assimilation model (Brown 2007; Bean et al. 2015) but with a slight twist. What we have analyzed here does not appear to be as straightforward as delayed or downward assimilation: Latino homeowners who experience deportation of a household member already achieved a measure of upward mobility - home ownership. In this regard, our analysis squares with others who find high rates of intergenerational mobility (Vallejo 2012; Kiester, Vallejo, and Borelli 2015). Yet, these intergenerational gains in home ownership may be vulnerable to foreclosure during an era of mass deportation of Latino immigrants. 
The results of this analysis underscore the emergence of legal status as an axis of stratification that uniquely disadvantages Latinos through racially disproportionate rates of deportation. The ensuing consequences of foreclosure for Latino households of reduced home ownership and wealth illustrate how legal status and racialized patterns of deportation act to stratify Latinos' housing outcomes and impede social mobility. Our results raise important questions about the fragility of social mobility achieved via home ownership and Latino stratification along America's evolving racial color line (e.g., Bonilla-Silva 2002; Gans 2005; Golash-Boza 2006; Lee and Bean 2010; Lichter 2013; Massey 2013). Rapid ascent into government-subsidized home ownership was a sufficient condition for wealth-building among whites in the twentieth century. For millions of Latino households, plummeting home equity and home ownership have been devastating in the twenty-first century context of risky lending and the foreclosure crisis.

In the continuing deportation crisis, undocumented and mixed legal statuses are also linked to the residential and racial stratification of Latinos today. As the country prepares for the possibility of increased enforcement and mass deportations, the lessons learned from this analysis take on new meaning and have increased relevance. Policymakers and advocates would be wise to consider the wide-reaching repercussions of enforcement for individuals, families, and communities, both in the short and long terms.

\section{Notes}

1 The surge in noncriminal deportations was even steeper. Noncriminal removals doubled from 50,901 in 2002 to 115,513 by 2006, peaked at 173,212 in 2009 (3.4 times the 2002 total), and remained elevated at 145,802 in 2012 (ICE 2013). Warren and Warren (2013) report that the number of unauthorized immigrants removed after living in the United States for more than six months doubled from 65,279 in 2000 to 133,190 in 2007, then rose to 164,839 in 2009. Extrapolating the prior rate of increase (5 percent) in deportations in the years leading up to 2002, one would expect 1.62 million deportations from 2003-2012. Instead, the actual total was a staggering 2.43 million. In other words, as a result of the post-2002 surge in deportations, there were an estimated additional 810,000 immigrants deported-and 72 percent were noncriminal deportations.

2 During the housing boom, multiple families were more common among Latino owneroccupied (homeowner) households, an indicator that Latinos were more likely to rely on multiple wage earners to make mortgage payments. In 2006, 15.2 percent of Hispanicheaded homeowner households in the United States contained multiple families, nearly twice the rate (7.8 percent) among non-Hispanic white homeowner households. In the expensive housing markets of Los Angeles and Washington, D.C., the rate among Hispanic homeowner households stood at 21.7 percent and 25.4 percent, respectively, compared to only 10.6 percent to 8.2 percent of such white households (authors' calculations based on March 2006 Current Population Survey).

3 Based on recent examination of thousands of Latino loan borrowers and the types of identity documents used to sign mortgages (e.g., driver's license, passport, green card, etc.), Rugh and Allen (2015) estimate that at most five to eight percent of Latino borrowers who signed mortgage loans were recent noncitizen residents or unauthorized immigrants without driver's licenses. 
4 Longitudinal data on Hispanic and immigrant movers further underscore how nativity and citizenship status combined to undermine home ownership among Latino households. Net of other factors, immigrant Hispanics are no less likely than native Hispanics to transition to first-time home ownership, with transitions primarily during the 2004-2006 housing boom; however, immigrant Hispanics were 1.7 times more likely to exit ownership, mainly during the 2007-2009 housing crash (Mundra 2013). Among immigrants of all races and ethnicities, noncitizens were roughly 1.5 times more likely to exit ownership (Mundra 2013). These longitudinal trends suggest that first-time ownership among Latino noncitizen households was especially vulnerable during the housing downturn.

5 Because the interviews took place in 2008 and 2009, 50 percent is likely a conservative estimate (right-censored) because other families may have lost homes later. Nonetheless, results from Chaudry et al. (2010) are a useful indicator of what the immediate first-year effect of detention and deportation may have on home ownership stability.

6 The implicit assumption in this approach is that racial group members face the same risk of foreclosure within neighborhoods and are only differentiated by the relative size of their group. While most of the variation in foreclosures exists across neighborhoods, there is some evidence that black and Hispanic mortgage holders are more likely than whites in the same neighborhood to foreclose. The implication is that we are likely slightly underestimating foreclosures to blacks and Hispanics. Importantly, however, there is no reason to believe this source of measurement error varies by county 287(g) status.

7 Ideally, the denominator in our foreclosure rate measures would refer to the number of housing units in a block at the start of each calendar year, but intercensal housing counts for each block are not available, and it is not possible to estimate these midpoints because block boundaries routinely change and normalizing these boundaries is not possible as no lower-level of census geography exists. Instead, we reran our analysis using normalized block group data from Geolytics (2015) and estimated racial group and housing counts at the start of each year by fitting a regression of 1990, 2000, and 2010 Census tabulations for each block group. The foreclosure measures based on this alternative approach are virtually identical to the measures based on census blocks ( $r=$ 0.988), and final results are statistically and substantively equivalent to those presented here.

8 In addition, highway patrols in two states-Missouri and Rhode Island-signed statelevel 287(g) agreements. However, neither program was implemented on a major scale and together detained only 21 persons (see DHS 2016). As these agreements conceivably affect all counties of a state, we considered excluding the 9 counties in our sample in Missouri and Rhode Island, but results from those models were identical to those presented here.

9 Counties are excluded from the analysis if PUMA boundaries cannot be constructed to capture at least 80 percent of the total population; among the omitted counties are nine that implemented 287(g) (Pinal, Arizona, Whitfield, Georgia, Frederick, Maryland, Gaston, North Carolina, Henderson, North Carolina, Washington, Utah, Loudoun, Virginia, Rockingham, Virginia, and Shenandoah, Virginia). As expected, omitted counties have smaller populations, lower Hispanic shares, less severe housing price escalation, and fewer foreclosures.

10 Segregation is calculated via the dissimilarity score between Hispanics and whites based on the census blocks within counties from Summary File 1 of Census 2000. To remove the 
influence of prison populations on these measures, we exclude from these calculations blocks where 25 percent or more of the population is institutionalized.

\section{References}

Alba, Richard D., and Victor Nee. 2005. Remaking the American Mainstream: Assimilation and Contemporary Immigration. Cambridge, MA: Harvard University Press.

Allen, Ryan. 2011. “The Relationship between Residential Foreclosures, Race, Ethnicity, and Nativity Status." Journal of Planning Education and Research 31(2): 125-42. https: //doi.org/10.1177/0739456X11398044

Amuedo-Dorantes, Catalina, and Thitima Puttitanun. 2014. "Remittances and Immigration Enforcement." IZA Journal of Migration 3:6. https : //doi . org/10 .1186/2193-9039-3-6

Bachmeier, James D., Jennifer Van Hook, and Frank D. Bean. 2014. “Can We Measure Immigrants' Legal Status? Lessons from Two U.S. Surveys." International Migration Review 48(2):538-566. https : //doi .org/10.1111/imre.12059

Bean, Frank, Susan K. Brown, and James D. Bachmeier. 2015. Parents without Papers: The Progress and Pitfalls of Mexican American Integration. New York, NY: Russell Sage Foundation.

Bocian, Debbie Gruenstein, Wei Li, Carolina Reid, and Roberto G. Quercia. 2011. Lost Ground, 2011: Disparities in Mortgage Lending and Foreclosures. Washington, DC: Center for Responsible Lending.

Bohn, Sarah, and Todd Pugatch. 2015. "U.S. Border Enforcement and Mexican Immigrant Location Choice." Demography 52(5):1543-1570. https://doi.org/10.1007/ s13524-015-0416-z

Bonilla-Silva, Eduardo. 2002. “We are All Americans!: The Latin Americanization of Racial Stratification in the USA." Race \& Society 5(2):3-16. https : //doi . org/10.1016/j . racsoc . 2003.12.008

Brabeck, Kalina, and Qingwen Xu. 2010. “The Impact of Detention and Deportation on Latino Immigrant Children and Families: A Quantitative Exploration." Hispanic Journal of Behavorial Sciences 32(3):341-361. https : //doi . org/10.1177/0739986310374053

Brown, Susan K. 2007. "Delayed Spatial Assimilation: Multigenerational Incorporation of the Mexican-Origin Population in Los Angeles." City E Community 6(3):193-209. https://doi.org/10.1111/j.1540-6040.2007.00213.x

Cahill, Meagan E., and Rachel S. Franklin. 2013. "The Minority Homeownership Gap, Foreclosure, and Nativity: Evidence from Miami-Dade County." Journal of Regional Science 53(1):91-117. https://doi .org/10.1111/jors. 12014

Capps, Randy, and Karina Fortuny. 2006. "Immigration and Child and Family Policy." Paper prepared for The Urban Institute and Child Trends Roundtable on Children in Low-Income Families. Washington, DC: The Urban Institute. http://www.urban.org/sites/default/files/alfresco/publication-pdfs/ 311362-Immigration-and-Child-and-Family-Policy.PDF

Capps, Randy, Marc R. Rosenblum, Cristina Rodríguez, and Muzaffar Chishti. 2011. Delegation and Divergence: A Study of 287(g) State and Local Immigration Enforcement. Washington, DC: Migration Policy Institute.

Capps, Randy, James D. Bachmeier, Michael Fix, and Jennifer Van Hook. 2013. A Demographic, Socioeconomic, and Health Coverage Profile of Unauthorized Immigrants in the United States. Washington, DC: Migration Policy Institute. 
Capps, Randy, Heather Koball, Andrea Campetella, Krista Perreira, Sarah Hooker, Juan Manuel Pedroza. 2015. Implications of Immigration Enforcement Activities for the Well-Being of Children in Immigrant Families. Washington, DC: Urban Institute and Migration Policy Institute.

Cardoso, Jodi Berger, Erin Randle Hamilton, Nestor Rodríguez, Karl Eschbach, and Jacqueline Hagan. 2014. "Deporting Fathers: Involuntary Transnational Families and Intent to Re-migrate among Salvadoran Deportees." International Migration Review, 1747-7379. http://dx.doi.org/10.1111/imre.12106

Chaudry, Ajay, Randy Capps, Juan Manuel Pedroza, Rosa Maria Castaneda, Robert Santos, and Molly M. Scott. 2010. Facing Our Future: Children in the Aftermath of Immigration Enforcement. Washington, DC: Urban Institute.

Chávez, Leo R. 2008. The Latino Threat: Constructing Immigrants, Citizens, and the Nation. Stanford, CA: Stanford University Press.

De Genova, Nicholas P. 2002. "Migrant 'Illegality' and Deportability in Everyday Life." Annual Review of Anthropology 31:419-447. https://doi .org/10.1146/annurev . anthro . 31.040402 .085432

Dreby, Joanna. 2012. "The Burden of Deportation on Children in Mexican Immigrant Families." Journal of Marriage and Family 74(4):829-845. https://doi .org/10.1111/j . $1741-3737.2012 .00989 . x$

Dreby, Joanna. 2015. Everyday Illegal: When Policies Undermine Immigrant Families. Berkeley, CA: University of California Press.

Fischer, Mary J., and Marta Tienda. 2006. "Redrawing Spatial Color Lines: Latino Metropolitan Dispersal, Segregation, and Economic Opportunity." In Marta Tienda and Faith Mitchell, eds. Latinos and the Future of America. Washington, D.C.: National Academies Press.

Gans, Herbert. 2005. "Race as Class." Contexts 4(4):17-21. Washington, DC: American Sociological Association. https://doi.org/10.1525/ctx.2005.4.4.17

Golash-Boza, Tanya. 2006. "Dropping the Hyphen? Becoming Latino(a)-American through Racialized Assimilation." Social Forces 85(1):27-55. https://doi.org/10.1353/sof . 2006.0124

Golash-Boza, Tanya. 2015. Deported: Immigrant Policing, Disposable Labor, and Global Capitalism. New York: New York University Press. https://doi.org/10.18574/nyu/ 9781479894666.001.0001

Golash-Boza, Tanya, and Pierrette Hondagneu-Sotelo. 2013. "Latino Immigrant Men and the Deportation Crisis: A Gendered Racial Removal Program." Latino Studies 11(3):271-292. https://doi.org/10.1057/lst.2013.14

Guelespe, Diana Maritza. 2013. "Second Class Families: The Challenges and Strategies of Mixed-Status Immigrant Families." Dissertations. Paper 668. Chicago: Loyola University Chicago. http://ecommons.luc.edu/luc_diss/668

Gonzalez-Barrera, Ana, and Jens Manuel Krogstad. 2014. U.S. Deportations of Immigrants Reach Record High in 2013. Washington, DC: Pew Research Center.

Hagan, Jacqueline Maria, Nestor Rodriguez, and Brianna Castro 2011. "Social Effects of Mass Deportations by the United States Government, 2000-10." Ethnic and Racial Studies 34(8):1374-1391. https://dx.doi.org/10.1080/01419870.2011.575233

Hall, Matthew. 2013. "Residential Integration on the New Frontier: Immigrant Segregation in Established and New Destinations." Demography 50(5):1873-1896. https : //doi .org/ 10.1007/s13524-012-0177-x 
Hall, Matthew, Kyle Crowder, and Amy Spring. 2015a. "Neighborhood Foreclosures, Racial/Ethnic Transitions, and Residential Segregation." American Sociological Review 80(3):526-49. https://doi .org/10.1177/0003122415581334

Hall, Matthew, Kyle Crowder, and Amy Spring. 2015b. "Variations in Housing Foreclosures by Race and Place, 2005-2012." The ANNALS of the American Academy of Politcal and Social Science 660(1):217-237. https : //doi .org/10.1177/0002716215576907

Hall, Matthew, and Emily Greenman. 2013. "Neighborhood and Housing Quality among Undocumented Immigrants." Social Science Research 42(6): 1712-1725. http://dx. doi. org/10.1016/j.ssresearch.2013.07.011

Hall, Matthew, and Jonathan Stringfield. 2014. "Undocumented Migration and the Residential Segregation of Mexicans in New Destinations." Social Science Research 47(3):61-78. https://doi.org/10.1016/j.ssresearch.2014.03.009

Immergluck, Dan. 2015. Preventing the Next Mortgage Crisis: The Meltdown, the Federal Response, and the Future of Housing in America. Lanham, MD: Rowman \& Littlefield.

Immigration and Customs Enforcement. 2013. FOIA Library. http://www.ice.gov/foia/ library

Keister, Lisa A., Jody Agius Vallejo, and E. Paige Borelli. 2015. “Mexican American Mobility: Early Life Processes and Adult Wealth Ownership." Social Forces. 93(3):1015-1046. https : //doi.org/10.1093/sf/sou102

Koball, Heather, Randy Capps, Kristin Perreira, Andrea Campetella, Sarah Hooker, Juan Manuel Pedroza, William Monson, and Sandra Huerta. 2015. Health and Social Service Needs of US-Citizen Children with Detained or Deported Immigrant Parents. Washington, DC: Urban Institute and Migration Policy Institute.

Kochhar, Rakesh, Ana Gonzalez-Barrera, and Daniel Dockterman. 2009. Through Boom and Bust: Minorities, Immigrants, and Homeownership. Washington, DC: Pew Hispanic Center.

Kostandini, Genti, Elton Mykerezi, and Cesar Escalante. 2014. “The Impact of Immigration Enforcement on the U.S. Farming Sector." American Journal of Agricultural Economics 96(1):172-192. https://doi .org/10.1093/ajae/aat081

Kuebler, Meghan, and Jacob S. Rugh. 2013. “New Evidence on Racial and Ethnic Disparities in Homeownership in the United States from 2001 to 2010." Social Science Research 42:1357-1374. http://dx.doi.org/10.1016/j.ssresearch.2013.06.004

Lacayo, A. Elena. 2010. “The Impact of Section 287(g) of the Immigration and Nationality Act on the Latino Community." National Council of La Raza.

Lee, Jennifer, and Frank D. Bean. 2010. Diversity Paradox: Immigration and the Color Line in Twenty-First Century America. New York: Russell Sage Foundation.

Lichter, Daniel T. 2013. "Integration or Fragmentation? Racial Diversity and the American Future." Demography 50(3):359-391. https://doi.org/10.1007/s13524-013-0197-1

Massey, Douglas S. 2013. “Immigration Enforcement as a Race-Making Institution.” Pp. 357-81 in David Card and Steven Raphael, eds., Immigration, Poverty, and Socioeconomic Inequality. New York: Russell Sage Foundation.

Massey, Douglas S., and Chiara Capoferro. 2008. “The Geographic Diversification of U.S. Immigration." Pp. 25-50 in Douglas S. Massey, ed., New Faces in New Places: The Changing Geography of American Immigration. New York: Russell Sage Foundation.

Massey, Douglas S., Jorge Durand, and Karen A. Pren. 2014. “Explaining Undocumented Migration to the U.S." International Migration Review 48(4):1028-1061. https : //doi .org/ 10.1111/imre. 12151 
Massey, Douglas S., Jorge Durand, and Karen A. Pren. 2016. "Why Border Enforcement Backfired" American Journal of Sociology 121(5): 1557-1600. https://doi .org/10. 1086/ 684200

Menjívar, Cecilia. 2006. “Liminal Legality: Salvadoran and Guatemalan Immigrants' Lives in the United States." American Journal of Sociology 111(4):999-1037. https ://doi .org/10. $1086 / 499509$

Menjívar, Cecilia. 2014. "Immigration Law Beyond Borders: Externalizing and Internalizing Border Controls in an Era of Securitization." Annual Review of Law and Social Science 10:353-369. https://doi.org/10.1146/annurev-lawsocsci-110413-030842

Miles, Thomas J., and Adam B. Cox. 2014. “Does Immigration Enforcement Reduce Crime? Evidence from Secure Communities." Journal of Law and Economics 57(4):937-973. https : //doi.org/10.1086/680935

Morgan, Stephen L., and Jennifer J. Todd. 2008. "A diagnostic routine for the detection of consequential heterogeneity of causal effects." Sociological Methodology 38(1):231-281. https://doi.org/10.1111/j.1467-9531.2008.00204.x

Mundra, Kusum. 2013. “Minority and Immigrant Homeownership Experience: Evidence from the 2009 American Housing Survey." IZA Discussion Paper No. 7131.

Myers, Dowell. 2007. Immigrants and Boomers: Forging a New Social Contract for the Future of America. New York, NY: Russell Sage Foundation.

Park, Julie, and Dowell Myers. 2010. "Intergenerational Mobility in the Post-1965 Immigration Era: Estimates by an Immigrant Generation Cohort Method." Demography 47(2):369-92. https://doi.org/10.1353/dem.0.0105

Passel, Jeffrey S., and D’Vera Cohn. 2014. Unauthorized Immigrant Totals Rise in 7 States, Fall in 14: Decline in Those from Mexico Fuels Most State Decreases. Washington, DC: Pew Research Center.

Pfeiffer, Deirdre, Karna Wong, Paul Ong, and Melany De La Cruz-Viesca. 2014. Pathways to Trouble: Homeowners and the Foreclosure Crisis in Los Angeles Ethnic Communities. Los Angeles: UCLA Asian American Studies Center.

Rosenblum, Marc R., and Kristen McCabe. 2014. “Deportation and Discretion: Reviewing the Record and Options for Change." Washington, DC: Migration Policy Institute.

Rugh, Jacob S. 2015a. "Double Jeopardy: Why Latinos Were Hit Hardest by the US Foreclosure Crisis." Social Forces 93(3): 1139-84. https ://doi .org/10.1093/sf/sou107

Rugh, Jacob S. 2015b. "Painting the Whole Picture: Foreclosure Rates among Asian American Ethnic Groups in Orlando, Florida, and Phoenix, Arizona." AAPI Nexus: Asian Americans and Pacific Islanders Policy, Practice E Community 13(1-2): 149-177. http: //dx. doi .org/ 10.17953/1545-0317.13.1.149

Rugh, Jacob S., and Ryan Allen. 2015. “Using Original Data to Uncover Pathways to Latino Disparities in Foreclosure." Paper presented at the Meeting of Urban Affairs Association, Miami, FL (April 9, 2015).

Rugh, Jacob S., and Douglas S. Massey. 2010. "Racial Segregation and the American Foreclosure Crisis." American Sociological Review 75(5):629-651. https : //doi .org/10.1177/ 0003122410380868

Schueths, April M. 2015. "Life and Love Outside the Citizenship Binary: The Lived Experiences of Mixed-Status Couples in the United States." Pp. 23-36 in April M. Schueths and Jodie M. Lawston, eds., Living Together, Living Apart: Mixed Status Families and US Immigration Policy. Seattle, WA: University of Washington Press. 
Taylor, Paul, Mark Hugo Lopez, Jeffrey S. Passel, and Seth Motel. 2011. Unauthorized Immigrants: Length of Residency, Patterns of Parenthood. Washington, DC: Pew Research Center.

Telles, Edward E., and Vilma Ortiz. 2008. Generations of Exclusion: Mexican Americans, Assimilation, and Race. New York: Russell Sage Foundation.

Thomas, Hannah. 2013. "The Financial Crisis Hits Home: Foreclosures and Asset Exhaustion in Boston." Housing Policy Debate 23(4): 738-764. https: //doi .org/10. 1080/10511482. 2013.828766

U.S. Department of Homeland Security. 2014. Yearbook of Immigration Statistics: 2013.

U.S. Department of Homeland Security. 2015. ICE FOIA Case Number 2015-ICFO-89811.

U.S. Department of Homeland Security. 2016. “Delegation of Immigration Authority Section 287(g) Immigration and Nationality Act" Fact Sheet. Available at: https://www.ice. gov/factsheets/287g\#wcm-survey-target-id

U.S. Government Accountability Office. 2009. Immigration Enforcement: Better Controls Needed over Program Authorizing State and Local Enforcement of Federal Immigration Laws. Washington, DC: Government Printing Office.

Vallejo, Jody Agius. 2012. Barrios to Burbs: The Making of the Mexican-American Middle Class. Stanford, CA: Stanford University Press. https://doi .org/10.11126/stanford/ 9780804781398.001 .0001

Van Hook, Jennifer, James D. Bachmeier, Donna Coffman, and Ofer Harel. 2015. "Can We Spin Straw Into Gold? An Evaluation of Immigrant Legal Status Imputation Approaches." Demography 52(1):329-354. https : //doi .org/10.1007/s13524-014-0358-x

Warren, Robert, and John Robert Warren. 2013. “Unauthorized Immigration to the United States: Annual Estimates and Components of Change, by State, 1990 to 2010." International Migration Review 47(2):296-329. https : //doi .org/10.1111/imre. 12022

Watson, Tara. 2013. "Enforcement and Immigrant Location Choice." NBER Working paper w19626. Cambridge, MA: National Bureau of Economic Research.

Zayas, Luis. 2015. Forgotten Citizens: Deportation, Children, and the Making of American Exiles and Orphans. Oxford: Oxford University Press.

Acknowledgements: We are very grateful to Jim Bachmeier for county unauthorized data and to Stephanie Potochnick, Juan Pedroza, and William Rosales for sharing 287(g) rejection FOIAs. We also thank Doug Massey, Jordan Matsudaira, Jody Vallejo, Scott Sanders, and Jon Jarvis for their helpful comments on earlier drafts.

Jacob S. Rugh: Department of Sociology, Brigham Young University. E-mail: jacob_rugh@byu.edu.

Matthew Hall: Department of Policy Analysis and Management, Cornell University. E-mail: mhall@cornell.edu. 